\title{
Harnessing place attachment for local climate mitigation? Hypothesising connections between broadening representations of place and readiness for change
}

Upham, Paul; Johansen, Katinka; Bögel, Paula Maria; Axon, Stephen; Garard, Jennifer; Carney, Sebastian

Published in:

Local Environment: The international journal of justice and sustainability

Link to article, DOI:

$10.1080 / 13549839.2018 .1488824$

Publication date:

2018

Document Version

Peer reviewed version

Link back to DTU Orbit

Citation $(A P A)$ :

Upham, P., Johansen, K., Bögel, P. M., Axon, S., Garard, J., \& Carney, S. (2018). Harnessing place attachment for local climate mitigation? Hypothesising connections between broadening representations of place and readiness for change. Local Environment: The international journal of justice and sustainability, 23(9), 912-919. https://doi.org/10.1080/13549839.2018.1488824

\section{General rights}

Copyright and moral rights for the publications made accessible in the public portal are retained by the authors and/or other copyright owners and it is a condition of accessing publications that users recognise and abide by the legal requirements associated with these rights.

- Users may download and print one copy of any publication from the public portal for the purpose of private study or research.

- You may not further distribute the material or use it for any profit-making activity or commercial gain

- You may freely distribute the URL identifying the publication in the public portal 
Published as Upham, P., Johansen, K., Bögel, P.M., Axon, S., Garard J., Carney, S. (2018) Harnessing place attachment for local climate mitigation? Hypothesising connections between broadening representations of place and readiness for change, Local Environment, online 21.06.18. https://doi.org/10.1080/13549839.2018.1488824

\title{
COMMENTARY FOR LOCAL ENVIRONMENT
}

\section{Harnessing place attachment for local climate mitigation? Hypothesising connections between} broadening representations of place and readiness for change

\begin{abstract}
Public engagement in local environmental planning and decision-making is often advocated on various grounds, both instrumental and normative. Yet in developed countries in the context of renewable energy infrastructure deployment, place attachment, place identity and place protective action continue to be implicated in public objection. We set out an interdisciplinary change readiness hypothesis of specifically how local participatory scenario or visioning processes that include climate mitigation measures may support the mobilization of place attachment for climate mitigation, including renewable energy deployment. We hypothesise that local visioning may support movement towards change readiness by helping to anchor unfamiliar social representations of low carbon energy infrastructure and new patterns of urban form in existing, more positive representations of localities and associated attachments. To this end, seeking ways to modify threat perceptions relating to climate change and renewable energy infrastructure is advocated as a key direction for study.
\end{abstract}

\section{Place attachment: negative versus positive role in energy transitions}

In general psychological terms, place attachment can be defined as an affective bond connecting people to places (Manzo, 2005). From such a perspective, place attachment essentially concerns 
Published as Upham, P., Johansen, K., Bögel, P.M., Axon, S., Garard J., Carney, S. (2018) Harnessing place attachment for local climate mitigation? Hypothesising connections between broadening representations of place and readiness for change, Local Environment, online 21.06.18. https://doi.org/10.1080/13549839.2018.1488824

the bonds between people and the environments that they consider significant or meaningful (Scannell \& Gifford, 2010). While the place attachment literature is large and varied, in summary one can say that it spans physical, psychological and social dimensions (Scannell \& Gifford, 2013; van Veelen \& Haggett, 2016). Environmental psychologists tend to view place psychology as comprising affective, cognitive and behavioural dimensions, which in turn may involve associated memories, beliefs, meaning and knowledge (Devine-Wright, 2009). Others taking a more sociological perspective have viewed place as a social construction (e.g. Alkon and Traugot, 2008). Phenomenological approaches view place as that where, for example, 'actions, experiences, intentions, and meanings are drawn together spatially' (Casey, 2009 and Relph, 1976, in Seamon, 2013), such that place as considered here is neither ontologically nor analytically separable from human experience. Here, we take a specifically social psychological perspective, while acknowledging that there are other perspectives that provide different ways of understanding place, including the geographical (e.g. Agnew, 1993). In general, regardless of perspective, place is viewed as a part of individual and shared identities that often have historical and cultural dimensions, all of which may also lead to a more or less deep-rooted sense of belonging, the intensity of which may be (and may be viewed as) mediated by many other factors (Devine-Wright, 2009; Hay, 1998; van Veelen \& Haggett, 2016).

Place attachment among publics has mostly been studied as playing a negative role in energy transitions (e.g. Devine-Wright, 2009; Feola and Nunes, 2014; Murphy and Smith, 2013; Süsser et al., 2017). As said, proximate place - locality - is involved in place-protective action, which is in turn founded on place attachment and identity (Lewicka, 2011). Place-protective action is also 
Published as Upham, P., Johansen, K., Bögel, P.M., Axon, S., Garard J., Carney, S. (2018) Harnessing place attachment for local climate mitigation? Hypothesising connections between broadening representations of place and readiness for change, Local Environment, online 21.06.18. https://doi.org/10.1080/13549839.2018.1488824

involved in opposition to the deployment of renewable energy infrastructure (e.g. Devine-Wright, 2009 and 2013), despite this infrastructure being intended ultimately to indirectly benefit (multiple) localities. For objectors, while this reasoning may be understood, it is disagreed with on various grounds and in any case the proposed or actual changes to the places to which they are attached are viewed as unacceptable.

In contrast to the negative effect of place attachment on public perceptions of new renewable energy infrastructure, place attachment and identity can also be motivators for acting in ways that most would agree improve localities environmentally, such as voluntary participation in ecological conservation or other renovation projects. Discussion of the positive potential of place attachment is, however, little found in the climate mitigation or energy governance and policy literature. Rather such discussion is found in relation to, for example, concepts of environmental stewardship in the socio-ecological governance literature (e.g. Chapin III and Knapp, 2015) and in the environmental education (pedagogy) literature (e.g. Kudryavtsev et al., 2012). There is also a strand of literature that finds positive associations between pro-environmental behaviour and place attachment, for example in the context of tourism, particularly national park tourism: for a short review, see Ramkissoon and Mavondo (2017). Relatedly, Ramkissoon and Mavondo (2015) posit pro-environmental behavior as a key mediator between visitor place satisfaction and place attachment, with such behaviour including, for example, conservation volunteering, hence furthering the objective of sustainability in general.

In general, the local level consists of familiarities, forming the backdrop to the everyday. Yet, for many people, climate change and its impacts are still viewed as temporally and spatially remote, although personal experience - for example, of flooding - can help to bring the issue home 
Published as Upham, P., Johansen, K., Bögel, P.M., Axon, S., Garard J., Carney, S. (2018) Harnessing place attachment for local climate mitigation? Hypothesising connections between broadening representations of place and readiness for change, Local Environment, online 21.06.18. https://doi.org/10.1080/13549839.2018.1488824

in multiple senses (Spence et al., 2011). This primacy of the local and tangible can be understood in terms of construal-level theory, concerning psychological distance, which holds that objects physically closer to a person, nearer in time or more socially-relevant are perceived as more concrete, real and salient than abstractions (e.g. Trope and Liberman, 2016).

The importance of the local raises the question of to what extent - and how - place attachment, identity and place-protective action may be mobilised for, rather than against, infrastructural change: particularly new energy supply and storage infrastructure intended to reduce GHG emissions. In other words, how place-related motivators may be more positively harnessed, normatively speaking, as part of sense-making and sense-giving processes (e.g. Wieck et al., 2005).

Such harnessing is clearly a metaphor, but we use this advisedly given the disciplinary contentions around - and differences between - sociological and psychological approaches to attitude and behaviour change (Shove, 2010). From the perspective of practice-focused sociology, individuals are carriers of practice and that practice maintains and sometimes changes social and sociotechnical structures, with attitudes following accordingly (ibid). From psychological, environmental behaviour perspectives, behaviour is generally considered a function of attitudes, norms, values and sometimes also environmental self-identity (e.g. van der Werff and Steg, 2016) - that is, the role of attitudes is causally reversed relative to a practice perspective.

Harnessing place protection for sustainability gain is from a practice perspective a matter of instituting sociotechnical structures supportive of new practices - yet this is as much an end as a means and requires the very types of policy change that dominant structures resist (Geels, 2014). Similarly, from a psychological perspective, while it may be possible to anticipate who is more 
Published as Upham, P., Johansen, K., Bögel, P.M., Axon, S., Garard J., Carney, S. (2018) Harnessing place attachment for local climate mitigation? Hypothesising connections between broadening representations of place and readiness for change, Local Environment, online 21.06.18. https://doi.org/10.1080/13549839.2018.1488824

likely to hold a more globally-extended conception of place protection on the basis of their other attitudes, norms and values, it is quite another matter to engender such a conception in those who do not hold this view.

Our present proposal is consistent with the latter, but is situated in what is often (arguably) the more contentious context of renewable energy siting. While the connections between place perceptions, environmental commitment and managed interventions are rarely viewed as simple, the normative case for local public engagement in environmental decision-making is now commonplace in the environmental governance literature, with rationales ranging from legal compliance; increasing acceptance for utilitarian purposes; enhancing the legitimacy of development proposals; and building shared visions (Rowe and Frewer, 2005). What (to our knowledge) has been little examined or theorised, however, are the ways in which place attachment to areas viewed as 'close to home' might be mobilised in such a way that new renewable energy infrastructure is viewed as place protective rather than intrusive and threatening. In the next section we consider some of the conditions that would need to be satisfied, including and perhaps notably, that the planning process is viewed as 'just'.

\section{Justice, equity and participatory environmental planning}

Community engagement in many types of local planning processes is intended to support the inclusion and representation of citizens generally and marginalised groups in particular (Kosmicki and Long, 2016). In local environmental planning contexts, participatory scenario and visioning processes are examples of those both advocated and used in order to help support concepts of 'just sustainabilities' (Agyeman and Evans, 2004), particularly as an expression of 
Published as Upham, P., Johansen, K., Bögel, P.M., Axon, S., Garard J., Carney, S. (2018) Harnessing place attachment for local climate mitigation? Hypothesising connections between broadening representations of place and readiness for change, Local Environment, online 21.06.18. https://doi.org/10.1080/13549839.2018.1488824

procedural justice (Agyeman and Evans, 2003; Schlosberg and Carruthers, 2010; DueholmRasch and Köhne, 2017). The notion of just sustainabilities aligns with the concept of 'just transitions' (Swilling and Annecke, 2012), whereby inclusive public engagement is advocated to help avoid the reproduction or exacerbation of existing environmental inequalities, while preventing the development of new forms of inequity (Dueholm-Rasch and Köhne, 2017).

Dialogue processes almost inevitably reveal some degree of differing attitudes, values and vision, both among those involved and between those involved and those with greater institutional power, be this statutory, commercial or otherwise. Deliberative democracy techniques are intended to give a voice to those who might otherwise be excluded. Although the visions generated may be plural or consensual, in general there is a presumption that local engagement approaches help to reconcile differences between multiple energy and climate visions (Farrell et al., 2013; Elstub, 2014). Such democratic and consensus-building elements are congruent with the concept of procedural justice as well as meaningful and effective public engagement (Axon, 2016; Dueholm-Rasch and Köhne, 2017).

Drawing on social representations theory (Moscovici, 1988; 2000), this commentary discusses specifically how local participatory scenario or visioning processes that include climate mitigation measures may support the mobilization of place attachment for climate mitigation, particularly renewable energy deployment. We hypothesise that local visioning may support movement towards 'change readiness', by helping to anchor unfamiliar social representations of low carbon energy infrastructure and new patterns of urban form in existing, more positive representations of localities and associated attachments. We outline this hypothesis in more detail in the next section. 
Published as Upham, P., Johansen, K., Bögel, P.M., Axon, S., Garard J., Carney, S. (2018) Harnessing place attachment for local climate mitigation? Hypothesising connections between broadening representations of place and readiness for change, Local Environment, online 21.06.18. https://doi.org/10.1080/13549839.2018.1488824

\section{Connecting social representations and change readiness}

Our hypothesis proposes social representations as moderators of attitudinal change, leading to increased change readiness. In the following, we firstly introduce social representations theory and outline the hypothesized effect on change readiness. With an interest in energy siting controversy and climate mitigation generally, we here focus on the facilitation of positive social representations of associated infrastructure, as a complement to the attitudes and beliefs that constitute the key constructs of change readiness. Including representations in part reflects a view that psychological, social and cultural factors are all important influences on behaviour (Batel and Adams, 2016) and that they are mutually influencing (ibid). However it also reflects the emphasis on aesthetics, imagery and visual metaphor that often seems to accompany public objection to renewable (and other) energy infrastructure. Secondly, we define how we change readiness could be defined in the context of new renewable energy infrastructure and how it would affect it.

Social Representations theory (Moscovici, 1988) proposes two main processes involved in the acceptance and use of ideas that are new to people, of which anchoring is most relevant here. Anchoring is the process by which new ideas are categorised according to pre-existing cognitive frameworks, rendering the unfamiliar familiar. Those seeking to establish particular social representations - such as positive representations of energy infrastructure, new urban forms or policy proposals - generally aim to associate such novelties with that which is already familiar. By conventionalising new concepts and giving them a recognisable, common form, social communication and coordination is also enhanced. Social representations are often contested and involve the expression of power: as we are socialised, 'they are forced upon us, transmitted, and 
Published as Upham, P., Johansen, K., Bögel, P.M., Axon, S., Garard J., Carney, S. (2018) Harnessing place attachment for local climate mitigation? Hypothesising connections between broadening representations of place and readiness for change, Local Environment, online 21.06.18. https://doi.org/10.1080/13549839.2018.1488824

are the product of a whole sequence of elaborations and of changes which occur in the course of time and are the achievement of successive generations' (Moscovici, 2000: 22, 24). Thus representations are competitive and dynamic, changing as new ideas jostle for acceptance.

Moscovici also describes social representation as: "systems of values, ideas and practices with a two-fold function; first, to establish an order which will enable individuals to orientate themselves in their material and social world and to master it; secondly, to enable communication to take place amongst members of a community by providing them with a code for social exchange and a code for naming and classifying unambiguously the various aspects of their world and their individual and group history" (Moscovici, 1973). In other words, meaning is not inherent in an object or situation, but is created through a system of social negotiation based on sharing values, ideas and practices.

We hypothesise that change readiness will mediate between social representations of new energy or climate mitigation infrastructure and acceptance-related attitudes. Holt et al. (2007) define change readiness as comprehensive attitude that is influenced by the content (the specific attitudes potentially subject to change); specific aspects of the process intended to bring about change; the attributes of individuals involved; and the attributes of the context (Fagernæs, 2015). This breadth enables the inclusion of a wide variety of explanatory accounts and indeed disciplinary perspectives, although Fagernæs' (2015) review of the literature suggests a contemporary prevalence of attitudinal models.

One of the benefits of applying the idea of change readiness in a climate mitigation context is that it is both multifactorial and specifically change-oriented, features that are arguably apt given that change is often a key outcome sought from local public engagement. Rafferty et al (2013) 
Published as Upham, P., Johansen, K., Bögel, P.M., Axon, S., Garard J., Carney, S. (2018) Harnessing place attachment for local climate mitigation? Hypothesising connections between broadening representations of place and readiness for change, Local Environment, online 21.06.18. https://doi.org/10.1080/13549839.2018.1488824

suggest that change readiness is the most prevalent positive attitude toward change studied in the organizational change literature, but also argue that while there is agreement about the key cognitions or beliefs that underlie change readiness, less attention has been given to its affective dimensions (and also its multi-level nature, though this is less immediately relevant here) (ibid, $\mathrm{p}$. 111-112). It is this affective dimension, as well as cognitive dimensions, that we propose as likely to be most directly connected to the dimensions of place attachment.

Accordingly, we hypothesise that those who have stronger objections to renewable energy proposals: (a) are by definition less ready to accept the proposed changes to relevant places than those who do not hold the same level of objection; (b) hold a range of activated norms, attitudes and beliefs consistent with their position ${ }^{1}$; (c) that these attitudes and beliefs are associated with negative representations (ideas and imagery) of the proposed changes to place; and (d) that these representations are associated with negative affect (treated here as synonymous with emotion). We are aware that in terms of empirical investigation, this raises a variety of measurement issues that we do not enter into here: our primary purpose in this short article is to articulate a multivariate direction for research rather than measurement details.

\section{Public engagement}

How might the above, hypothesised connections be nurtured? While many of the primary effects of climate change may be global, the causes are located within the inter-related climate-relevant

\footnotetext{
${ }^{1}$ We say activated because inconsistent attitudes (for example) may co-exist but be subject to different levels of activation, the latter being associated with a point in time relating to decision-making or action - i.e. we may often experience ambivalence but at some point make a choice, consciously or unconsciously (Cacioppo et al, 1997).
} 
Published as Upham, P., Johansen, K., Bögel, P.M., Axon, S., Garard J., Carney, S. (2018) Harnessing place attachment for local climate mitigation? Hypothesising connections between broadening representations of place and readiness for change, Local Environment, online 21.06.18. https://doi.org/10.1080/13549839.2018.1488824

practices of business and industry, individuals, households and communities. With over one-third of many developed nations' carbon emissions attributable to domestic energy use and private travel, individuals and communities have a key role to play in sustainable energy transitions (Whitmarsh et al., 2013). Whether one conceives of practices or behaviour in this regard, central to much of the climate change debate is the consensus that changes to human practices/behaviour are required if we are to transition towards more sustainable methods of living (Axon, 2017).

Public engagement and participation in projects at the community level connects with the foregoing by enabling projects to be co-produced, co-governed and co-delivered, with the rationale that this often results in more meaningful engagement and involvement than top-down projects (see Alexander et al., 2007 and Heiskanen et al., 2010). Furthermore, community-based sustainability projects can engage residents in energy visioning exercises and pathway development that allow individuals to identify and potentially shape aspects of energy system futures (Morrissey et al., 2017). While this raises many questions as to exactly who to engage, how, when and what the relationships of informal engagement are or should be to formal processes of representative democracy, a variety of methods can be envisaged for consultation and engagement in sustainability transitions processes (Upham et al, 2015) and a large literature exists that spans a continuum ranging from one way communication to engagement involving negotiation (Rowe and Frewer, 2005).

Our hypothesis, set out in Figure 1, is that public (and stakeholder) engagement in low carbon scenario development may help to engender more positive meanings of renewable energy infrastructure, not through community ownership models per se (though these may be involved), but by catalysing new understandings of place - new sense-making and sense-giving - in which 
Published as Upham, P., Johansen, K., Bögel, P.M., Axon, S., Garard J., Carney, S. (2018) Harnessing place attachment for local climate mitigation? Hypothesising connections between broadening representations of place and readiness for change, Local Environment, online 21.06.18. https://doi.org/10.1080/13549839.2018.1488824

this infrastructure is viewed as a means of place protection rather than as a threat. Indeed Lewicka (2011) identifies meaning-making processes as among the most under-researched aspects of place attachment.

$<$ Please insert Figure 1>

Clearly there are limits as to what can be expected in this regard (Peters et al, 2013), as a result of engagement per se. Those with strongly held oppositional attitudes may not engage, may be obstructive and will likely filter communicative attempts in a manner consistent with prior opinions and representations (Tsang, 2017). Objectors may also have grounds for dissent (regardless of others' views of their justification) that relate to previous experience with institutionalised authority, with associated distrust. The least that can be recommended in this circumstance within the proposed explanatory frame is the use of intermediaries to whom more neutral representations are anchored.

Clearly, perceptions of the quality and the context of the engagement matter. Again we do not propose to have all the answers at hand for how these may be influenced, but the main correlative option that comes to mind is working to change the nature and magnitude of threat perceptions relating to renewable energy infrastructure and climate change, while being aware of the complexity of responses to attempts to make climate change more psychologically proximate (such as inadvertently making people feel overwhelmed and disempowered) (Brügger et al, 2015). The relationships between threat perceptions and social representations in relation to renewable energy infrastructure and climate change could be bidirectional, i.e. capable of mutual influence. 
Published as Upham, P., Johansen, K., Bögel, P.M., Axon, S., Garard J., Carney, S. (2018) Harnessing place attachment for local climate mitigation? Hypothesising connections between broadening representations of place and readiness for change, Local Environment, online 21.06.18. https://doi.org/10.1080/13549839.2018.1488824

\section{Conclusions}

In this commentary, we have raised a variety of issues and have mooted various ideas on the topic of mobilising place protective action for - rather than against - the deployment of renewable energy. We have suggested that seeking to change social representations and related threat perceptions of climate change and renewable energy, as part of and through public engagement processes, are key directions to consider when seeking to mobilise place attachment positively. We have mooted change readiness as a measurable moderator of change in this context and we offer these ideas with a view to stimulating further thought on the double-edged sword that place attachment arguably represents.

\section{References}

Agnew, J., 1993. Representing space: space, scale and culture in social science. , in: Place/Culture/Representation. pp. 251-271.

Agyeman, J. and Evans, T., 2003, Toward just sustainability in urban communities: Building equity rights with sustainable solutions, The Annals of the American Academy of Political and Social Science, 590, 35-53.

Agyeman, J. and Evans, B., 2004, 'Just sustainability': The emerging discourse of Environmental Justice in Britain?, The Geographical Journal, 170 (2), 155-164. 
Published as Upham, P., Johansen, K., Bögel, P.M., Axon, S., Garard J., Carney, S. (2018) Harnessing place attachment for local climate mitigation? Hypothesising connections between broadening representations of place and readiness for change, Local Environment, online 21.06.18. https://doi.org/10.1080/13549839.2018.1488824

Alexander, R., Hope, M. and Degg, M., 2007. Mainstreaming sustainable development - A case study: Ashton Hayes in Going Carbon Neutral. Local Economy, 22, 62-74.

Alkon, A. H., \& Traugot, M., 2008. Place Matters, But How? Rural Identity, Environmental Decision Making, and the Social Construction of Place. City \& Community, 7(2), 97-112. http://doi.org/10.1111/j.1540-6040.2008.00248.x

Armenakis, A. A., Bernerth, J. B., Pitts, J. P., \& Walker, H. J., 2007. Organizational change recepients' beliefs scale: Development of an assessment instrument. Journal of Applied Behavioral Science, 43, 481-505.

Axon, S., 2017. Keeping the ball rolling: addressing the enablers of, and barriers to, sustainable lifestyles. Journal of Environmental Psychology, 52, 11-25.

Batel, S., Devine-Wright, P., \& Tangeland, T., 2013. Social acceptance of low carbon energy and associated infrastructures: a critical discussion. Energy Policy, 58, 1-5.

http://doi.org/10.1016/j.enpol.2013.03.018

Batel, S. \& Adams, M. (2016). Ecological crisis, sustainability and social worlds: Developing a critical agenda. Papers on Social Representations, 25(1), 1.1-1.27.

Batel, S., Castro, P., Devine-Wright, P., \& Howarth, C., 2016. Developing a critical agenda to understand pro-environmental actions: contributions from Social Representations and Social Practices Theories. Wiley Interdisciplinary Reviews: Climate Change, 7(5), 727-745. http://doi.org/10.1002/wcc.417 
Published as Upham, P., Johansen, K., Bögel, P.M., Axon, S., Garard J., Carney, S. (2018) Harnessing place attachment for local climate mitigation? Hypothesising connections between broadening representations of place and readiness for change, Local Environment, online 21.06.18. https://doi.org/10.1080/13549839.2018.1488824

Bouckenooghe, D., Devos, G., \& Van den Broeck, H., 2009. Organizational change questionnaire - climate of change, processes, and readiness: development of a new instrument. Journal of Psychology, 143, 559-599.

Brügger, A., Dessai, S., Devine-Wright, P., Morton, T.A., Pidgeon, N.F., 2015. Psychological responses to the proximity of climate change. Nature Climate Change 5, 1031.

Carney, S. \& Shackley, S., 2009. The greenhouse gas regional inventory project (GRIP): designing and employing a regional greenhouse gas measurement tool for stakeholder use. Energy Policy, 37, 4293-4302.

Cacioppo, J. T., Gardner, W. L., \& Berntson, G. G., 1997. Beyond Bipolar Conceptualizations and Measures: The Case of Attitudes and Evaluative Space. Personality and Social Psychology Review, 1(1), 3-25. http://doi.org/10.1207/s15327957pspr0101_2

Casey, E. S. 2009. Getting back into place, Bloomington, Indiana University Press.

Devine-Wright, P., 2009. Rethinking NIMBYism: the role of place attachment and place identity in explaining place-protective action. Energy and Environment, 20, 303-317.

Devine-Wright, P., 2013. Explaining “NIMBY” Objections to a Power Line: The Role of Personal, Place Attachment and Project-Related Factors. Environment and Behavior, 45(6), 761781. http://doi.org/10.1177/0013916512440435

Dueholm-Rasch, E. and Köhne, M., 2017. Practices and imaginations of energy justice in transition. A case study of the Noordoostpolder, the Netherlands. Energy Policy, 107, 607-614.

Elstub, S., 2014, Mini-publics: issues and cases, in Elstub, s. and McLaverty, P. (eds.) Deliberative democracy: issues and cases, Edinburgh: Edinburgh University Press, pp.166-188. 
Published as Upham, P., Johansen, K., Bögel, P.M., Axon, S., Garard J., Carney, S. (2018) Harnessing place attachment for local climate mitigation? Hypothesising connections between broadening representations of place and readiness for change, Local Environment, online 21.06.18. https://doi.org/10.1080/13549839.2018.1488824

Farrell, D. M., O'Malley, E. and Suiter, J. 2013, Deliberative democracy in action Irish-style:

The 2011 we the citizens pilot citizens' assembly, Irish Political Studies, 28(1), 99-113.

Feola, G. \& Nunes, R., 2014. Success and failure of grassroots innovations for addressing climate change: The case of the Transition Movement. Global Environmental Change, 24, 232250.

Fagernæs, K.L.M., 2015. Measuring change readiness How to successfully quantify readiness for change, Master's Thesis, University of Oslo, Oslo, https://www.duo.uio.no/bitstream/handle/10852/44724/Masteroppgave_KristinaLMFagernaes.pd $\underline{\text { f? sequence }=1}$

Geels, F.W., 2014. Regime Resistance against Low-Carbon Transitions: Introducing Politics and Power into the Multi-Level Perspective. Theory, Culture \& Society, 31, 21-40. http://doi.org/10.1177/0263276414531627

Heiskanen, E., Johnson, M., Robinson, S., Vadovics, E. \& Sasstamoinen, M., 2010. Low-carbon communities as a context for individual behavioural change. Energy Policy, 38, 7586-7595.

Holt, D.T., Armenakis, A.A., Harris, S. G., \& Feild, H.S., 2007. Toward a comprehensive definition of readiness for change: A review of research and instrumentation. In W.A. Pasmore \& R.W. Woodman, eds. Research in organizational change and development, Oxford: Elsevier, vol. 16 , pp. 289-336. 
Published as Upham, P., Johansen, K., Bögel, P.M., Axon, S., Garard J., Carney, S. (2018) Harnessing place attachment for local climate mitigation? Hypothesising connections between broadening representations of place and readiness for change, Local Environment, online 21.06.18. https://doi.org/10.1080/13549839.2018.1488824

Kosmicki, M. S. and Long, M. A., 2016, Exploring environmental inequality within US

Communities containing coal and nuclear power plants. In Hazardous Waste and Pollution. Springer International Publishing, pp. 79-99.

Kudryavtsev, A., Krasny, M.E., \& Stedman, R.C., 2012. The impact of environmental education on sense of place among urban youth. Ecosphere, 3(4), 1-15. http://doi.org/10.1890/ES11-

\section{1}

Holt, D. T., Armenakis, A. A., Feild, H. S., \& Harris, S. G. 2007. Readiness for Organizational Change: The Systematic Development of a Scale. Journal of Applied Behavioral Science, 43(2), 232-255. doi: 10.1177/0021886306295295

Lewicka, M., 2011. Place attachment: How far have we come in the last 40 years? Journal of Environmental Psychology, 31(3), 207-230. http://doi.org/http://dx.doi.org/10.1016/j.jenvp.2010.10.001

Morrissey, J., Axon, S., Aiesha, R., Hillman, J., Lennon, B. \& Dunphy, N., 2017. Energy system visioning and low-carbon configurations. Liverpool: Liverpool John Moores University for ENTRUST European Union project.

Moscovici, S., 1988. Notes towards a description of social representations. European Journal of Social Psychology 18, 211-250.

Patterson, M.E., Williams, D.R., 2005. Maintaining research traditions on place: Diversity of thought and scientific progress. Journal of Environmental Psychology 25, 361-380. doi:https://doi.org/10.1016/j.jenvp.2005.10.001 
Published as Upham, P., Johansen, K., Bögel, P.M., Axon, S., Garard J., Carney, S. (2018) Harnessing place attachment for local climate mitigation? Hypothesising connections between broadening representations of place and readiness for change, Local Environment, online 21.06.18. https://doi.org/10.1080/13549839.2018.1488824

Peters, M., Fudge, S. \& Hoffman, S., 2013. The persistent challenge of encouraging public participation in the low-carbon transition. Carbon Management, 4, 373-375.

Rafferty, A.E., Jimmieson, N.L. and Armenakis, A.A., 2013. Change Readiness: A Multilevel Review. Journal of Management, 39, p. 110-135.

Ramkissoon, H., and Mavondo, F. T., 2015. The satisfaction- place attachment relationship:

Potential mediators and moderators. Journal of Business Research, 68, 2593-2602.

Ramkissoon, H., Mavondo, F.T., 2017. Proenvironmental behavior: Critical link between satisfaction and place attachment in Australia and Canada. Tourism Analysis 22, 59-73. doi:10.3727/108354217X14828625279735

Relph, E. 1976. Place and Placelessness, Pion, London.

Rowe, G. and Frewer, L.J., 2005. A Typology of Public Engagement Mechanisms. Science, Technology, \& Human Values, 30 (2), 251-290. DOI: 10.1177/0162243904271724

Scannell, L. and Gifford, R., 2013. Personally relevant climate change: The role of place attachment and local versus global message framing in engagement. Environment and Behaviour, 45, 60-85.

Schlosberg, D. and Carruthers, D., 2010. Indigenous struggles, environmental justice, and community capabilities. Global Environmental Politics, 10(4), 12-35.

Seamon, D., 2013. Place attachment and phenomenology: The synergistic dynamism of place, in: Place Attachment: Advances in Theory, Methods and Applications. pp. 11-22. doi:10.4324/9780203757765 
Published as Upham, P., Johansen, K., Bögel, P.M., Axon, S., Garard J., Carney, S. (2018) Harnessing place attachment for local climate mitigation? Hypothesising connections between broadening representations of place and readiness for change, Local Environment, online 21.06.18. https://doi.org/10.1080/13549839.2018.1488824

Shove, E. (2010). Beyond the ABC: climate change policy and theories of social change.

Environment and Planning A, 42, 1273-1285. http://doi.org/10.1068/a42282

Spence, A., Poortinga, W., Butler, C. \& Pidgeon, N.F., 2011. Perceptions of climate change and willingness to save energy related to flood experience. Nature Climate Change, 1, 46-49.

Süsser, D., Döring, M., Ratter, B.M.W., 2017. Harvesting energy: Place and local entrepreneurship in community-based renewable energy transition. Energy Policy, 101, 332-341. Swilling, M. and Annecke, E., 2012. Just Transitions: Explorations of sustainability in an unfair world, Shibuya-ku, Tokyo: United Nations University Press.

Trope, Y., \& Liberman, N., 2010. Construal-Level Theory of Psychological Distance.

Psychological Review, 117(2), 440-463. http://doi.org/10.1037/a0018963

Tsang, J.S., 2017. Cognitive Discrepancy, Dissonance, and Selective Exposure. Media Psychol 1-24. doi:10.1080/15213269.2017.1282873.

Upham, P. Carney, S. \& Klapper, R., 2013. Scaffolding, narrative and software: engaging nonexperts in energy and emissions backcasting. Technological Forecasting and Social Change 81, $131-142$.

Upham, P., Virkamäki, V., Kivimaa, P., Hildén, M. and Wadud, Z., 2015. Socio-technical transitions governance and public opinion: the case of passenger transport in Finland. Journal of Transport Geography 46: 210:219. doi:10.1016/j.jtrangeo.2015.06.024

Upham, P., Klapper, R. and Carney, S., 2016. Participatory energy scenario development as dramatic scripting: A structural narrative analysis. Technological Forecasting and Social Change, 103, 47-56. doi:http://dx.doi.org/10.1016/j.techfore.2015.10.003 
Published as Upham, P., Johansen, K., Bögel, P.M., Axon, S., Garard J., Carney, S. (2018) Harnessing place attachment for local climate mitigation? Hypothesising connections between broadening representations of place and readiness for change, Local Environment, online 21.06.18. https://doi.org/10.1080/13549839.2018.1488824

van der Werff, E., \& Steg, L., 2016. The psychology of participation and interest in smart energy systems: Comparing the value-belief-norm theory and the value-identity-personal norm model. Energy Research \& Social Science, 22, 107-114. DOI: 10.1016/j.erss.2016.08.022

van Veelen, B., \& Haggett, C., 2016. Uncommon ground: The role of different place attachments in explaining community renewable energy projects. Sociologia Ruralis, online version http://doi.org/10.1111/soru.12128

Weick, K. E., Sutcliffe, K. M., \& Obstfeld, D., 2005. Organizing and the Process of Sensemaking. Organization Science, 16(4), 409-421. http://doi.org/10.1287/orsc.1050.0133

Whitmarsh, L., O'Neill, S. \& Lorenzoni, I., 2013. Public engagement with climate change: What do we know and where do we go from here? International Journal of Media and Cultural Politics, 9, 7-25. 
Published as Upham, P., Johansen, K., Bögel, P.M., Axon, S., Garard J., Carney, S. (2018) Harnessing place attachment for local climate mitigation? Hypothesising connections between broadening representations of place and readiness for change, Local Environment, online 21.06.18. https://doi.org/10.1080/13549839.2018.1488824

Figure 1 Hypothesised relationships between public engagement in local visioning, place attachment, threat perceptions and social representations of new energy infrastructure

Initial social

representations

of climate

mitigation

options
Mobilization of place

attachment via changed

threat perceptions

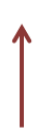

Participatory local scenario

and visioning
More positive

social

representations

of climate

mitigation

options

Increased

change

readiness 